\title{
Effect of Using Grape Seeds on Productive Performance and Nutrients Utilization for Broiler Chicks during Fattening Period \\ Tag El-Din, T. H. ${ }^{1}$; A. L. Awad ${ }^{2}$ and A. A. Sherief ${ }^{1}$ \\ ${ }^{1}$ Poultry Production Dept., Fac. of Agric., Damietta Univ \\ ${ }^{2}$ Anim. Prod. Res. Inst., Agric. Res. Centre, Egypt
}

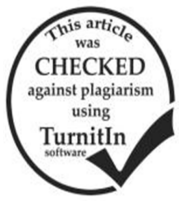

\section{ABSTRACT}

A total of 216 day old broiler chicks (Arbor Acers) were weighed and distributed into equal 4 experimental groups of three replicates for each to explore the effect of dietary grape seeds $(0,0.5,1.0$ and $1.5 \%)$ addition on growth parameters, nutrients utilization and carcass characteristics as well as economic efficiency during fattening period (1-35 days of age). The results indicated that live body weight, body weight gain , feed conversion ratio and production index traits significantly $(\mathrm{P} \leq 0.05)$ improved for chicks fed diet contained $1.0 \%$ grape seeds (GS), while these parameters recorded non-significant improvement by 0.50 and $1.5 \% \mathrm{GS}$ levels compared with chicks fed the control diet during the entire experimental period (0-35 days of age). Using GS in broilers diet recorded nonsignificant improvement for nutrients digestibility than the control except for fiber digestibility which was significantly improved. Feeding value improved $(\mathrm{P}>0.05)$ for chicks by dietary grape seeds addition. Total edible parts (\%) insignificantly elevated by feeding different GS diets than the control. Chicks fed 1.0\% GS diet recorded the best economic efficiency compared with the control at the entire experimental period. Therefore, it might be concluded that feeding diet contained $1.00 \%$ GS for broiler chicks might be used to improve growth performance and nutrients utilization as well as economic efficiency during the fattening period.

Keywords: broilers, grape seeds, growth, nutrient digestibility, carcass traits)

\section{INTRODUCTION}

Worldwide, creation of poultry meat and eggs and global consumption of poultry products, especially poultry meat, have expanded regularly over the years, and this pattern is required to proceed. Chick's meat and product have numerous attractive dietary qualities, for example, low lipid substance and relatively high concentrations of polyunsaturated fatty acids (Bourre, 2005). In addition, poultry meat is relatively low-priced compared to other meats.

Grapes (Vitis vinifera) are one of the world biggest fruit crop with yearly creation of 77 million metric tons (FAO, 2013). Processing of grapes for ethanol, fruit juice and wine creation results in tremendous quantities of by-products including stems, skins, seeds and peels, which approximately $20 \%$ of the weight of the grape used in making wine (Llobera and Canellas, 2007). These by-products are wealthy in polyphenols like flavonoids, monomeric phenolic compounds, catechins, and epicatechins (Dorri et al., 2012). The grape polyphenols could play as powerful antioxidants by scavenging free-radicals and ending oxidative reactions (Brenes et al., 2016). When considering the different separate parts of grape pomace (seed and skin), the proportion of seeds ranges from $38 \%$ to $52 \%$ of the dry material and record for around $17 \%$ of the fresh grape pomace (Fernandes etal., 2013; Toscano et al., 2013). Grape seeds composition point out the content of fiber (40\%), essential oil (16\%), protein $(11 \%)$ and complex phenolic compounds (7\%) like tannins and other substances like sugars and minerals (Campos et al., 2008). Grape seeds have plentiful fat, mostly linoleic acid, followed by oleic, palmitic, stearic and myristic acids (Bravo and Saura-Calixto, 1998).

Grape by-products have been widely debated as antimicrobial activities and feed additives because they rich in polyphenols compounds, grape by-products has been shown to change the intestinal microflora status of chickens (Xia et al., 2010). Dietary polyphenols-rich grape products could be effective in expanding the growth of beneficial bacteria while intensely barring certain pathogenic bacteria, so grape by-products addition to broilers diet can be beneficial for producers (Viveros et al., 2011). Dietary grape seed extract have positive effects on the growth performance of broilers when added at low levels to the diets (Wang et al., 2008; Brenes et al., 2010). In a newfangled review, grape seeds extract (GSE) have decrease plasma lipid components (El-Damrawy, 2014), reinforce antioxidant and immunostimulant status (Katiyar, 2015). However, the addition of GSE with very high levels resulted in growth depression, Hughes et al. (2005) found that grape seed extract (GSE) addition with $30 \mathrm{~g} / \mathrm{kg}$ diet depress the performance of chickens, while Goni et al. (2007) and Brenes et al. (2008) stated that supplementing grape pomace by $30 \mathrm{~g} / \mathrm{kg}$ improved antioxidant status without any noxious effect on the performance of chickens.

Therefore, this study was designed to investigate the effects of dietary ground grape seeds addition on growth performance, nutrients utilization and carcass traits as well as economic efficiency for broiler chicks during fattening period (1-35 days of age).

\section{MATERIALS AND METHODS}

This study was carried out in a private ranch close near Kafr Saad city, Damietta Governorate, Egypt, during the period between the $17^{\text {th }}$ of October and $22^{\text {th }}$ of November 2018. A 216 day old unsexed commercial broiler chicks (Arbor Acers), were weighed and distributed into equal 4 experimental treatments of three replicates. Experimental groups were arranged as: the $1^{\text {st }}$ group fed on the basal experimental diet (control), the other three groups were fed diets contained ground grape seeds by $0.50,1.0$ and $1.50 \%$, respectively during the entire experimental period ( 35 days of age). Experimental groups were fed the starter diet during 1-14 days, then the grower diet from 14-28 days, while the finisher diet was used from 28-35 days of age. Experimental diets were similarly formulated to be isocaloric and nitrogenic to meet the broiler requirements according to NRC (1994). Diets composition and calculated analysis are available in Table 1.

Experimental chicks were raised under similar conditions. Feeds and fresh water were accessible ad- 
libitum through the experimental period. Chicks were kept under 23 hours light and one hour dark per day at the experimental period. Chicks immunized against Newcastle (NDV) disease virus and infectious broncheitis
(IB) at the first week of age, while Gumboro disease was vaccinated at the second week of age in drinking water. The anti-microbial drugs and vitamins were not used during the experimental period for all groups.

Table1. Experimental diets composition and calculated analysis

\begin{tabular}{|c|c|c|c|c|c|c|c|c|c|c|c|c|}
\hline \multirow{3}{*}{$\begin{array}{l}\text { Ing., } \\
\%\end{array}$} & \multirow{2}{*}{\multicolumn{4}{|c|}{$\begin{array}{c}\text { Starter diets } \\
\text { GS } \%\end{array}$}} & \multirow{2}{*}{\multicolumn{4}{|c|}{$\begin{array}{c}\text { Grower diets } \\
\text { GS, } \% \\
\end{array}$}} & \multirow{2}{*}{\multicolumn{4}{|c|}{$\begin{array}{c}\text { Finisher diets } \\
\text { GSs, \% }\end{array}$}} \\
\hline & & & & & & & & & & & & \\
\hline & 0.0 & 0.50 & 1.0 & 1.50 & 0.0 & 0.50 & 1.0 & 1.50 & 0.50 & 0.50 & 1.0 & 1.50 \\
\hline Corn & 54.0 & 53.55 & 53.0 & 52.5 & 61.0 & 60.4 & 59.7 & 59.0 & 66.2 & 65.6 & 64.9 & 64.2 \\
\hline Soybean (42\%) & 28.5 & 28.45 & 28.42 & 28.38 & 25.0 & 25.0 & 25.0 & 25.0 & 20.0 & 20.0 & 20.0 & 20.0 \\
\hline Gluten $(62 \%)$ & 10.0 & 10.0 & 10.0 & 10.0 & 5.6 & 5.6 & 5.6 & 5.6 & 4.5 & 4.5 & 4.5 & 4.5 \\
\hline Grape seed & 0.0 & 0.5 & 1.0 & 1.5 & 0.0 & 0.5 & 1.0 & 1.5 & 0.0 & 0.5 & 1.0 & 1.5 \\
\hline Mono. Cal & 1.6 & 1.6 & 1.6 & 1.6 & 1.6 & 1.6 & 1.6 & 1.6 & 1.6 & 1.6 & 1.6 & 1.6 \\
\hline Limestone & 1.6 & 1.6 & 1.6 & 1.5 & 1.6 & 1.6 & 1.6 & 1.6 & 1.65 & 1.65 & 1.65 & 1.65 \\
\hline Men. Vit. premix & 0.3 & 0.3 & 0.3 & 0.3 & 0.3 & 0.3 & 0.3 & 0.3 & 0.3 & 0.3 & 0.3 & 0.3 \\
\hline Salt & 0.35 & 0.35 & 0.35 & 0.35 & 0.30 & 0.30 & 0.3 & 0.3 & 0.35 & 0.35 & 0.35 & 0.35 \\
\hline Bicarbonate sodium & 0.1 & 0.1 & 0.1 & 0.1 & 0.1 & 0.1 & 0.1 & 0.1 & 0.1 & 0.1 & 0.1 & 0.1 \\
\hline Methionine & 0.1 & 0.1 & 0.1 & 0.1 & 0.1 & 0.1 & 0.1 & 0.1 & 0.1 & 0.1 & 0.1 & 0.1 \\
\hline Soya oil & 1.3 & 1.3 & 1.38 & 1.42 & 2.2 & 2.3 & 2.5 & 2.7 & 3.0 & 3.1 & 3.3 & 3.5 \\
\hline Lysine & 0.15 & 0.15 & 0.15 & 0.15 & 0.2 & 0.2 & 0.2 & 0.2 & 0.2 & 0.2 & 0.2 & 0.2 \\
\hline $\begin{array}{l}\text { Molasses } \\
\text { (dry matter basis) }\end{array}$ & 2.0 & 2.0 & 2.0 & 2.0 & 2.0 & 2.0 & 2.0 & 2.0 & 2.0 & 2.0 & 2.0 & 2.0 \\
\hline \multicolumn{13}{|c|}{ Calculated analysis } \\
\hline $\mathrm{CP}, \%$ & 23.01 & 23.00 & 23.00 & 23.00 & 19.45 & 19.46 & 19.46 & 19.45 & 17.11 & 17.11 & 17.11 & 17.11 \\
\hline $\mathrm{ME} \mathrm{kcal} / \mathrm{kg}$ & 3040 & 3029 & 3022 & 3013 & 3106 & 3100 & 3100 & 3100 & 3188 & 3179 & 3181 & 3181 \\
\hline $\mathrm{Ca}, \%$ & 0.96 & 0.96 & 0.96 & 0.96 & 0.95 & 0.95 & 0.95 & 0.96 & 0.95 & 0.96 & 0.96 & 0.96 \\
\hline Phos., \% & 0.46 & 0.46 & 0.46 & 0.46 & 0.45 & 0.45 & 0.45 & 0.45 & 0.44 & 0.44 & 0.44 & 0.44 \\
\hline CF., & 3.18 & 3.35 & 3.53 & 3.70 & 3.09 & 3.26 & 3.44 & 3.60 & 2.86 & 3.03 & 3.20 & 3.37 \\
\hline Cost of one $\mathrm{kg}, \mathrm{LE}$ & 6.862 & 6.840 & 6.827 & 6.809 & 6.576 & 6.569 & 6.572 & 6.575 & 6.286 & 6.279 & 6.282 & 6.285 \\
\hline
\end{tabular}

1.Vit and Min.( 3 kg) contains: Vit A 10 MIU, Vit. D 2 MIU, Vit E 10 g, Vit. K 2 g, Thi. 1 g, Ribo. 5 g, Pyrid. 1.5 g, Niac. 30 g, Vit. B12 10 mg, Panto. 10 g, Fol. 1.5 g, Biot.50 mg, Cho. Chl. 250 g, Man. 60 g, Zin. 50 g, Iro. 30 g, Cop. 10 g, Iod. 1 g, Sel.0. 10 g, Cob. 0.10 g. and carrier CaCO3 to $3000 \mathrm{~g}$.

2.NRC (1994).

3.Ingredients price (one kg, LE) at experiment time : corn , 3.90 ; Soy-bean meal, 9.20; gluten , 13.20 ; Mono-calcium Phosphate,16.50 ; limestone, 0.25 ; Vit\&Min.premx,60.0 ; Nacl,0.80, Lysine, 35.0 ; Methio.,80.0 ; soya oil (one liter), 14.00 and Molasses, 3.0 LE ; grape seed, 0.50 LE as well as manufacture process, $200.0 \mathrm{LE} /$ ton live bodyweight before slaughter.

Measurements and estimated parameters:

1. Growth parameters: Live body weight and feed consumption recorded weekly per each replicate of broiler chicks. Also, number of dead chicks was recorded during the whole experimental period. Weight gain, feed efficiency and production index were calculated at 1-14, 14-28, 28-35 and 1-35 days of age per replicate, while viability percentage of chicken's was calculated during the overall experimental period.

2. Digestion trial: At 32 days of age, feed consumption was recorded per each replicate, and excreta was pooled and thoroughly mixed per replicate for each treatment for three days. Feed and excreta samples were dried immediately for chemical analysis. Digestibility coefficients of DM, OM, CP, CF, EE and NFE were decided according to Jakobsen et al. (1960) ; Abou- Raya and Galal (1971), while TDN \% and ME (kcal/kg) were calculated.

3. Carcass traits: At the end of experiment, four chicks per treatment were randomly taken and representing the average body weight of each treatment, they fasted for 8 $\mathrm{h}$ and weighed individually before slaughter and after bleeding. Then, feather plucking and evisceration performed. Eviscerated carcass, giblets and abdominal fat were removed and weighed. Relative weights of carcass traits were communicated as a percentage of live bodyweight before slaughter.

4. Economic efficiency: Feeding cost was calculated using existing market prices of one $\mathrm{kg}$ of starter, grower and finisher diet consumed per each treatment, total costs calculated as a ratio of feeding cost (Singh et al., 2015).Sales revenue was determined by using the price of the poultry stock exchange for the kilo of current living weight at the experiment time.

5.Statistical analysis: Data were statistically analyzed according to SAS (2004) computer program using the following model:

$$
\mathbf{Y}_{\mathbf{i}}=\boldsymbol{\mu}+\mathbf{T}_{\mathbf{i}}+\mathbf{e}_{\mathbf{i}}
$$

Where: $Y_{i}=$ The observation; $\mu=$ Overall mean; $T_{i}=$ Effect of treatments $(i=1,2,3,4) ; e_{i}=$ Random error.

The differences between means were tested using Duncan's New Multiple Range Test (Duncan, 1955)

\section{RESULTS AND DISCUSSION}

\section{Growth performance:-}

Dietary grape seed (GS) addition had significant effect on live body weight (LBW) of broiler chicks at different ages (Table 2). Broilers LBW was significantly improved by $7.86 \%$ for broilers fed diet contained $10.0 \%$ GS, while it insignificantly improved by 5.08 and $2.71 \%$ for those fed 5.0 and $15.0 \%$ GS diets compared with those the control group at 35 days of age. On the other hand, body weight gain (BWG) was improved by feeding diets contained GS with or without significant effect (Table 2). Broilers BWG was significantly improved by about $8.05 \%$ for broilers reared on $10.0 \%$ GS diet, while it insignificantly 
improved by 5.22 and $2.78 \%$ for those fed 5.0 and $15.0 \%$ GS diets, respectively comparing to the control group at the entire experimental period ( 0 - 35 days of age). These findings are agreement with Abdallah et al. (2017) who reported that increasing grape seed addition to broilers diet resulted an increase in their final BW and BWG. Pascariu et al. (2017) found that LBW of broiler chicks fed $0.50 \% \mathrm{GS}$ in the diet recorded higher $(\mathrm{P}<0.01)$ increase than those fed diet contained grape pomace $(10,20 \mathrm{~g} / \mathrm{kg})$ and the control diet. Abu Hafsa and Ibrahim (2018) found that feeding diets containing $20 \mathrm{~g} \mathrm{GS} / \mathrm{kg}$ for broiler chicks had effective in enhancing growth performance. Also, body weight and body weight gain improved by dietary GS addition for broiler chickens (Brenes et al., 2008) and growing rabbits (Fawzia et al., 2014)on. However, the inclusion of GS in chicken diets did not change growth performance (Nardoia, 2016). These improvements may be due to grape seed could be increased villus height, absorptive surface area, enzymes expression and transport systems of nutrient which resulted an improved body weight gain (Viveros et al. 2011).Or they may be due to natural antioxidants in GS such as phenolic compounds can protect the intestinal mucosa from oxidative damage and pathogens as well as limit peristaltic activity in digestive disorders and reduce intestinal movement which lead to better nutrients absorption (Ismail et al., 2003).

Feed consumption (FC) was significantly affected due to feeding diet contained GS during different experimental period except for the periods of 14-28 and 1-35 day of age (Table 2). It was significantly increased by 8.18 $12.85 \%$ for broilers fed different GS diets than the control at $1-14$ days of age, while it was $(\mathrm{P} \leq 0.05)$ attenuated by $9.92 \%$ for broilers reared on $10.0 \%$ GS diet than the control at 2835 days of age. Generally, broilers FC amount was numerically similar among different experimental groups at 1-35 days of age. The present results are agreement with Aditya et al. (2018) who showed that dietary dried grape pomace supplementation didn't affect on feed consumption for broiler chicks. Abu Hafsa and Ibrahim (2018) concluded that, grape seeds addition by $20 \mathrm{~g} / \mathrm{kg}$ diet did not affect feed intake than the control. However, El-Kelawy et al. (2018) found that supplementing natural sources of polyphenols as grape seed (0.5 and $1.0 \%)$ had increased feed consumption. This result could be broilers able to regulate feed intake according to their energy requirements as well as the experimental diet had similar metabolizable energy.

Feed conversion ratio (FCR) was significantly improved by $8.18-10.06 \%$ for broilers fed different GS diets than the control at 1-14 days of age, while it significantly improved by $11.48 \%$ for broilers fed $10.0 \%$ GS diet than the control at 14-28 days of age only (Table 2). Generally, broilers fed diet contained GS recorded the best FCR than the control during the entire experimental period, it was improved by 4.17, 7.81 and $3.65 \%$ for broiler fed 5.0, 10.0 and $15.0 \%$ GS diet than the control, respectively.

Table 2. Effect of grape seeds on growth parameters for chicks during fattening period

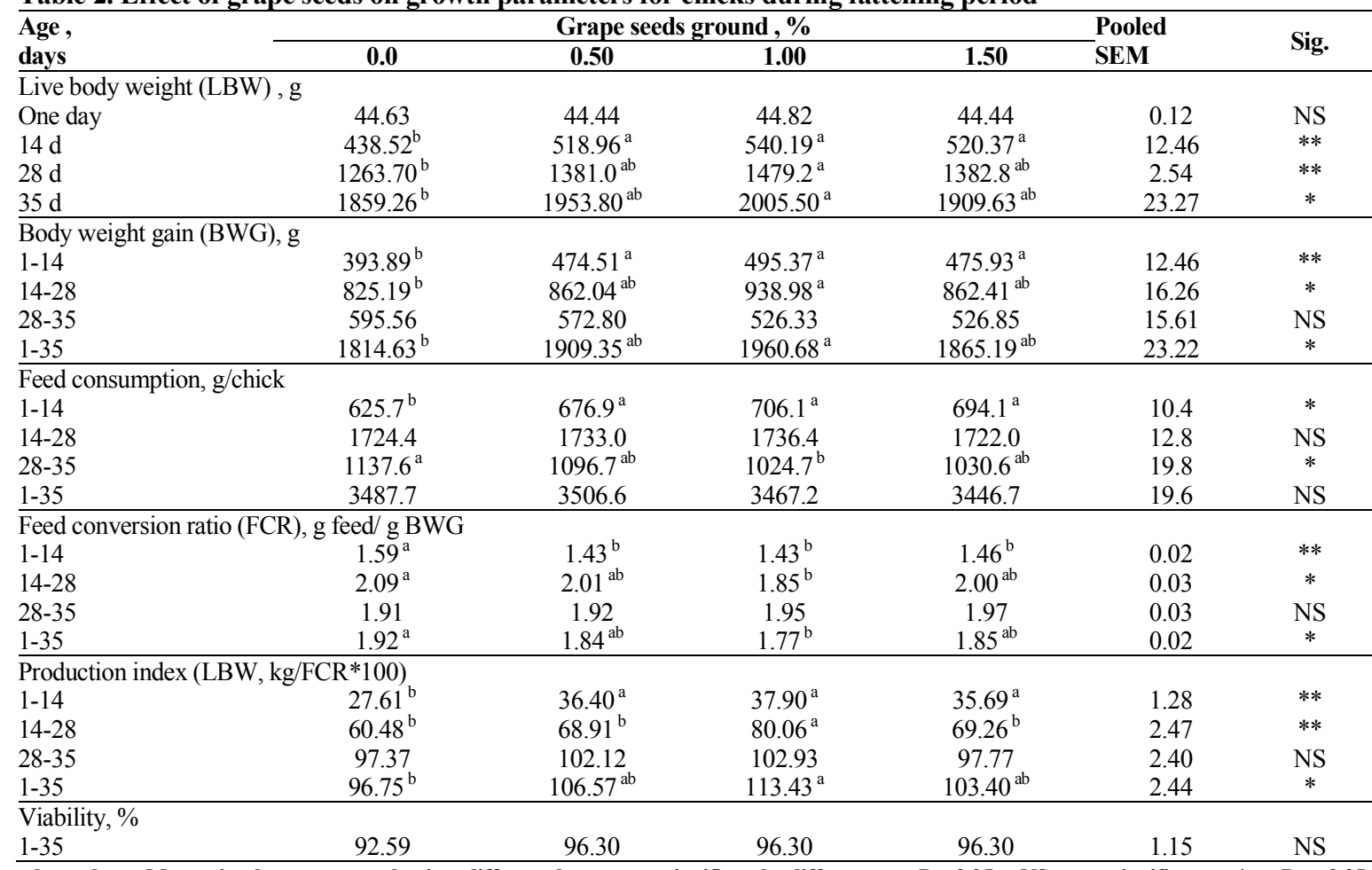

a,b, and $\mathrm{c}:$ Means in the same row having different letters are significantly different at $\mathrm{P} \leq 0.05 ; \quad \mathrm{NS}=$ not significant $; *=\mathrm{P} \leq 0.05$; $* *=*=\mathbf{P} \leq 0.01 ; \mathrm{SEM}=$ standard error mean

These results are agree with Chamorro et al. (2013) who concluded that dietary grape seeds extract up to 2.5 $\mathrm{g} / \mathrm{kg}$ diet had better FCR for chickens. Pascariu et al. (2017) reported that broilers received diet contained $5 \mathrm{~g} / \mathrm{kg}$ grape seeds, 10 and $20 \mathrm{~g} / \mathrm{kg}$ grape pomace has achieved a better FCR than the control. Also, El-Kelawy et al. (2018) reported that dietary natural sources of polyphenols supplementation had better feed conversion ratio than control groups. Abu Hafsa and Ibrahim (2018)found that, grape seeds addition by $20 \mathrm{~g} / \mathrm{kg}$ of broiler diet improved feed conversion ratio than the control. However, Aditya et al. (2018) found that dietary addition with dried grape pomace ( 5 up to $10 \mathrm{~g} / \mathrm{kg}$ ) for 
commercial broilers didn't effects $(\mathrm{P}>0.05)$ on feed conversion ratio than the control during the overall period.

The improvement in FCR is associated with decreasing FC and increasing LBW value which may be attributed to improve BWG of ducklings, or natural antioxidants in grape seeds can protect the intestinal mucosa from oxidative damage and pathogens as well as limit peristaltic activity in digestive disorders and reduce intestinal movement which lead to better nutrients absorption (Ismail et al., 2003).

A significant difference was observed among the experimental treatments in production index (PI) by dietary GS addition during different experimental intervals except of 28-35 days of age (Table 2). Broilers PI was significantly improved by $37.27,32.37$ and $17.24 \%$, respectively for broilers fed diet contained $10.0 \%$ GS at 1-14, 14-28 and 135 days of age comparing to the control group. These findings in the same line with Hajati et al. (2015) who showed that birds fed $300 \mathrm{mg}$ GSE/kg diet had higher production efficiency. El-Kelawy et al. (2018) reported that dietary natural sources of polyphenols addition of broiler had higher production index compared to Vit. E and control groups. The improvement in PI is associated with improving FCR and increasing LBW value as well as this might be due to the presence of flavonoids in GS which exhibit strong as antioxidant properties (Dorri et al., 2012). Also, grape seeds have antimicrobial activity against pathogenic bacteria (Cabuk et al., 2003)

Broiler viability (\%) was insignificantly higher by using different GS levels in the diet than the control during the entire experimental period. These results are agreement with Wang et al. (2008) who reported that the lowest mortality for chicks fed diet supplemented with grape seed proanthocyanidin extract (10 to $20 \mathrm{mg} / \mathrm{kg}$ ) than the control group. This may be due to GS which plays a vital role as antimicrobial in alleviates remarkably the intestine microbial populations and prevents the lysis of amino acids which is used in proteinic tissues (Lee et al., 2001). Also, it may be due to the biological function of phenolic compounds in GS as well that show antioxidant activity which decrease oxidative damage (Xia et al., 2010).

\section{Nutrients digestibility coefficients:-}

Non-significant differences in all studied nutrient digestibility coefficient and feeding value for broiler chicks by feeding GS diet except of crude fiber (Table 4). Crude fiber digestibility was significantly improved by 33.31 , 31.22 and $47.81 \%$ for broiler fed diet contained $0.50,1.00$ and $1.5 \%$ GS than those fed the control diet. In the other hand, dry and organic matter, crude protein, ether extract and nitrogen free extract digestibility's were insignificantly improved by feeding diet contained different GS than the control. Also, feeding value was insignificantly improved by different GS diets comparing to the control. These results are agree with Brenes et al. (2008) who found that grape pomace (GP) addition to broilers diet didn't effect on digestibility of $\mathrm{CP}$, while ether extract digestibility was reduced in birds fed control and GP diets compared with birds fed vitamin E. Brenes et al. (2010) showed that dietary GSE addition ( 0.6 up to $3.6 \mathrm{~g} / \mathrm{kg}$ ) increased ileal digestibility of crude protein at 21 days of age. Similarly, Aditya et al. (2018) found that nutrients digestibility were did not affect $(\mathrm{P}>0.05)$ due to grape pomace (GP) addition with 5.0 up to
$10.0 \mathrm{~g} / \mathrm{kg}$, except for digestibility of ash than the control, while chicks fed 5.0 or $7.5 \mathrm{~g} \mathrm{GP} / \mathrm{kg}$ diets recorded the highest digestibility of DM, CP and EE than other treatment. These results could be due to the improvements in nutrients enzymatic digestion, a high absorption capacity of the intestinal epithelium and enhanced fermentation activity of intestinal microflora. Also, grape seeds could increase intestinal villus width and height which results in an increase in absorptive surface area, enzymes expression, nutrient transport systems, and an improved nutrient digestibility (Viveros et al., 2011).

\section{Carcass traits:-}

Both eviscerated carcass and total edible parts (\%) were numerically similar for broiler chicks in different experimental groups by feeding different grape seeds diets at 35 days of age (Table 3). Relative eviscerated carcass weight was insignificantly increased by $2.53,2.08$ and $1.28 \%$, while total edible parts (\%) was increased by 2.36 , 1.87 and $0.81 \%$, respectively for chicks fed diet contained $0.50,1.00$ and $1.5 \%$ GS comparing to the control group at 35 days of age. Also, feeding diets contained GS can effect on relative weights of some body organs with or without significant effect. Moreover, abdominal fat (\%) was insignificantly elevated by feeding GS diet comparing to the control. These findings are in the same line with Brenes et al. (2010) who showed that dietary GSE addition didn't effect on relative weights of pancreas, liver and liver as well as abdominal fat compared with the control for broiler chicks. Also, dietary supplementation of GSE didn't affect the percentage of edible carcass, liver and abdominal fat of birds (Hajati et al., 2015). Similarly, Aditya et al. (2018) reported that carcass traits for commercial broilers were not significantly affected by GP addition $(5,7.5$ and $10 \mathrm{~g} / \mathrm{kg}$ ) compared with the control. Dietary grape pomace $(5,7.5$ and $10 \%$ ) addition had no significant effect on relative weights of carcass, abdominal fat, liver and heart for broilers (Ebrahimzadeh et al., 2018). El-Kelawy et al. (2018) found that natural sources of polyphenols supplementations to broiler chickens diet increased percentage of dressing and total edible parts compared with control. However, Abu Hafsa and Ibrahim (2018) found that dietary grape seed (GS) addition with $20 \mathrm{~g} / \mathrm{kg}$ diet had significant elevation of carcass yield, dressing and gizzard \%, while $40 \mathrm{~g} / \mathrm{kg}$ of GS resulted a significant reduced of abdominal fat $\%$ than the control. The increase of eviscerated carcass and total eating parts percentage may be due to decreasing un-edible parts as a result of GS addition to the diet. The decrease of abdominal fat (\%) may be due to GS prevents fatty tissue buildup, decreases the calorie requirement and increases the tolerance to effort because it may plays as antioxidant material which elevates the $\beta$-oxidation of these fatty acids in order to generate adenosine triphosphate (ATP) energy and increase energy utilization by reduce the amount of long-chain fatty acids for esterification to triacylglycerols and storage in the adipose tissue.

\section{Economic evaluation:-}

Economic evaluation parameters were illustrated in in Table 5. Total cost was decreased by GS addition to the diet with 10.0 or $15.0 \%$ level. Total return at 35 days of age was improved by different GS addition levels than the control. Generally, net return and EEF values were elevated by feeding different GS diets than the control, 
EEF values were improved by $12.83,23.81$ and $10.90 \%$ for broilers fed diet contained $0.50,10.0$ and $15.0 \% \mathrm{GS}$, than those fed the control diet. It's clearly that the GS addition by $10.0 \%$ to broilers diet resulted in the best EEF during the entire experimental period for broilers.

Table 3. Effect of grape seeds addition on carcass parameters for chicks at 35 days of age.

\begin{tabular}{|c|c|c|c|c|c|c|}
\hline \multirow{2}{*}{ Items } & \multicolumn{4}{|c|}{ Grape seeds ground,$\%$} & \multirow{2}{*}{$\begin{array}{l}\text { Pooled } \\
\text { SEM }\end{array}$} & \multirow{2}{*}{ Sig. } \\
\hline & 0.0 & 0.50 & 1.00 & 1.50 & & \\
\hline \multicolumn{7}{|c|}{ Carcass parameters } \\
\hline . & 1865.0 & 1935.0 & 2036.0 & 2014.0 & 38.9 & $\mathrm{~N}$ \\
\hline $\begin{array}{l}\text { ated } \\
\%\end{array}$ & 70.78 & 72.57 & 72.25 & 71.69 & 0.37 & \\
\hline lets, $\%$ & 4.22 & 4.20 & 4.15 & 3.92 & 0.08 & NS \\
\hline lible & 75.00 & 76.77 & 76.40 & 75.61 & 0.37 & \\
\hline al fat $\%$ & 1.44 & 1.80 & 1.59 & 1.67 & 0.09 & $\mathrm{Ns}$ \\
\hline \multicolumn{7}{|c|}{ Relative weights of some body organs } \\
\hline & & 2.54 & 2.32 & 2.12 & 0.08 & $\mathrm{~N}$ \\
\hline & & & & & & \\
\hline & & & & & 02 & $\mathrm{~N}$ \\
\hline & & & & & & \\
\hline Pancreas & 0.26 & 0.23 & 0.20 & 0.21 & 0.018 & $\mathrm{~N}$ \\
\hline
\end{tabular}

a,b, : Means in the same row having different letters are significantly different at $\mathrm{P} \leq 0.05 ; \mathrm{NS}=$ not significant ; $*=\mathrm{P} \leq 0.05$;

SEM = standard error mean

Table 4. Effect of grape seeds addition on nutrients digestibility and feeding value for chicks at 32 days of age.

\begin{tabular}{lcccccc}
\hline \multirow{2}{*}{ Items } & \multicolumn{3}{c}{ Grape seeds powder, \% } & Pooled & Sig. \\
\cline { 2 - 6 } & $\mathbf{0 . 0}$ & $\mathbf{0 . 5 0}$ & $\mathbf{1 . 0 0}$ & $\mathbf{1 . 5 0}$ & SEM & \\
\hline Dry matter, \% & 79.15 & 80.51 & 81.40 & 81.58 & 0.65 & $\mathrm{NS}$ \\
Organic matter, \% & 81.43 & 82.43 & 83.81 & 83.34 & 0.58 & $\mathrm{NS}$ \\
Ash- retention, \% & 39.88 & 42.50 & 44.23 & 40.81 & 1.99 & $\mathrm{NS}$ \\
Crude protein, \% & 64.59 & 69.06 & 70.10 & 71.52 & 1.33 & $\mathrm{NS}$ \\
Crude fiber, \% & $38.40^{\mathrm{b}}$ & $51.19^{\mathrm{a}}$ & $50.39^{\mathrm{a}}$ & $56.76^{\mathrm{a}}$ & 2.38 & $* *$ \\
Ether extract, \% & 53.27 & 55.70 & 57.31 & 59.73 & 1.20 & $\mathrm{NS}$ \\
Nitrogen free extract, \% & 90.80 & 90.45 & 92.07 & 90.65 & 0.39 & $\mathrm{NS}$ \\
\hline \multicolumn{7}{c}{ Feeding value } \\
TDN, \% & 80.91 & 82.61 & 84.14 & 85.19 & 0.72 & $\mathrm{NS}$ \\
ME $(\mathrm{kcal} / \mathrm{kg})$ & 3382.0 & 3453.2 & 3517.1 & 3560.8 & 3.00 & $\mathrm{NS}$ \\
\hline
\end{tabular}

a,b, : Means in the same row having different letters are significantly different at $\mathrm{P} \leq \mathbf{0 . 0 5} ; \mathrm{NS}=$ not significant ; $* *=\mathrm{P} \leq 0.01$;

SEM = standard error mean; $\mathrm{TDN}=$ total digestibility of nutrients; $\mathrm{ME}=$ metabolizable energy

Table 5. Effect of grape seeds addition on economic evaluation parameters for chicks at experimental period.

\begin{tabular}{lcccc}
\hline \multirow{2}{*}{ Items } & \multicolumn{4}{c}{ Grape seeds ground, g/kg } \\
\cline { 2 - 5 } & $\mathbf{0 . 0}$ & $\mathbf{5 . 0}$ & $\mathbf{1 0 . 0}$ & $\mathbf{1 5 . 0}$ \\
\hline Total feed cost, LE & 22.78 & 22.90 & 22.67 & 22.53 \\
Total cost LE $^{\mathbf{1}}$ & 32.54 & 32.71 & 32.39 & 32.19 \\
Total return LE $^{\mathbf{3}}$ & 50.20 & 52.75 & 54.15 & 51.56 \\
Net return LE $^{\mathbf{y}}$ & 17.66 & 20.04 & 21.76 & 19.37 \\
Economic efficiency LE $^{\mathbf{5}}$ & 0.543 & 0.612 & 0.672 & 0.602 \\
EE of the control LE $^{\mathbf{6}}$ & 100.0 & 112.83 & 123.81 & 110.90 \\
\hline
\end{tabular}

L.E. $=$ Egyptian pound.

1-Total feed cost $=$ the cost of starter, grower and finisher diet consumed.

2-Total cost calculated as total feed cost equal 70\% of total cost (Singh et al., 2015)

3 - Total return $=$ Live body weight $*$ price of one $\mathrm{kg}$ at selling which was 27.0 L.E.

4-Net return $=$ total return - total cost

5-Feeding economic efficiency $(\%)=$ Net revenue (L.E) $/$ Total cost (L.E).

6-Assuming that the relative economic efficiency of control group which equal 100.

\section{CONCLUSION}

The obtained data showed that grape seed addition with $10.0 \%$ to broilers diet could be used to improve growth parameters, nutrient utilization and carcass parameters and economic efficiency under Egyptian environmental conditions.

\section{REFERENCES}

Abdallah, E.A.; Abd El-Samad MH; Abdel latif AM; Rezk AM and Doaa MMY., 2017. Effect of dietary supplementation of grape seed extract or vitamin e as antioxidant on reproductive and physiological performance during summer season. 2- aged males developed chickens. Egypt. Poult. Sci., 37 (I): 137-153

Abou- Raya, A. K. and Galal, AG., 1971. Evaluation of poultry feeds in digestion trails with reference to some factors involved. U.A.R. (Egypt), Anim. Prod. , 11: 207 - 221.

Abu Hafsa, SH and Ibrahim S A., 2018. Effect of dietary polyphenol-rich grape seed on growth performance, antioxidant capacity and ileal microflora in broiler chicks. J Anim Physiol Anim Nutr. 102:268-275

Aditya, S; Ohh SJ ; Ahammed M and Lohakare J., 2018. Supplementation of grape pomace (Vitis vinifera) in broiler diets and its effect on growth performance, apparent total tract digestibility of nutrients, blood profile, and meat quality. Animal Nutrition, 4: 210e214

Bourre, JM., 2005. Where to find omega-3 fatty acids and how feeding animals with diet enriched in omega-3 fatty acids to increase nutritional value of derived products for human: What is actually useful? The Journal of Nutrition Health and Aging, 9, 232-242.

Bravo, L and Saura-Calixto F., 1998. Characterization of dietary fiber and the in vitro indigestible fraction of grape pomace. American Journal of Enology and Viticulture, 49, 135-141.

Brenes, A.; Viveros A; Goni I; Centeno C; Sayago-Ayerdi SG; Arija I and Saura-Calixto F., 2008. Effect of grape pomace concentrate and vitamin $\mathrm{E}$ on digestibility of polyphenols and antioxidant activity in chickens. Poul. Sci. 87, 307-316.

Brenes, A; Viveros A; Goni I; Centeno C; Saura CF and Arija I., 2010. Effect of grape seed extract on growth performance, protein and polyphenol digestibilities and antioxidant activity in chicken. Span J Agric Res, 8: 326-333.

Brenes, A; Viveros A; Saura C and Arija I., 2016. Use of Polyphenol-rich grape by-products in monogastric nutrition. Anim. Feed Sci.Technol. 1,1-17.

Cabuk, M; Alcicek A; Bozkurt M and Imre N., 2003. Antimicrobial alternative feed additives. 11. National Animal Nutrition Congress, Pp: 184-187.

Campos, LMAS; Leimann FV; Pedrosa RC and Ferreira SRS., 2008. Free radical scavenging of grape pomace extracts from Cabernet Sauvingnon (Vitis vinifera). Bioresource Technology, 99, 8413-8413.

Chamorro, S; Viveros A; Centeno C; Romero C; Arija I and Brenes A., 2013. Effects of dietary grape seed extract on growth performance, amino acid digestibility and plasma lipids and mineral content in broiler chicks. Animal, 7, 555-561.

Dorri, S; Tabeidian AS; Toghyani M; Jaha-nian R and Behnamnejad F., 2012. Effect of different levels of grape pomace on blood serum and biochemical parameters of broiler chicks at 29 and 49 days of age. Proc. 11th Int. and 4th Natl. Congress on Recycling of Organic Waste in Agriculture. Isfahan, Iran 
Duncan, D.B. (1955).Multiple range and multiple $\mathrm{F}$ tests. Biometrics, 11:1-42.

Ebrahimzadeh, SK; Navidshad B; Farhoomand $\mathrm{P}$ and Aghjehgheshlagh FM., 2018.Effects of grape pomace and vitamin $\mathrm{E}$ on performance, antioxidant status, immune response, gut morphology and histopathological responses in broiler chickens. South African J. of Anim. Sci. , 48 (No. 2): 324-336

El-Damrawy, SZ., 2014. Effect of grape seed extract on some physiological changes in broilers under heat stress. Egyptian Poultry Science Journal 34, 333-343.

El-Kelawy, MI; ELnaggar AS and Abdelkhalek E., 2018.Productive performance, blood parameters and Immune response of broiler chickens supplemented with grape seed and medicago sativa as natural Sources of polyphenols. Egypt Poult. Sci.vol., 38: 269-288

FAO, 2013. STAT-FAO Stastical Data-base, http://faostat3. fao. Org

Fawzia, AH; Khalid Mand Basyony M M., 2014. Influence of grape seeds powder as a natural Antioxidant on growth performance, antioxidant Status and carcass characteristics of rabbits under hot conditions. Proceedings of the 7th International Conference on Rabbit Production in Hot Climate, 8-12 September, 2014, Marsa Alam, Egypt, pp. 395-412

Fernandes, L; Casal S; Cruz R; Pereira JA and Ramalhosa E., 2013. Seed oils of ten traditional Portuguese grape varieties with interesting chemical and antioxidant properties. Food Research International, 50(1), 161-166.

Goni, I; Brenes A; Centeno C; Viveros A; Saura-Calixto A; Rebole I and Arija R., 2007. Effect of Dietary Grape Pomace and Vitamin E on Growth Performance, Nutrient Digestibility, and Susceptibility to Meat Lipid Oxidation in Chickens. Poult. Sci. 86, 508-516.

Hajati, H; Ahmad H; Abolghasem G; Hassan N and Mohammad R., 2015. The Effect of Grape Seed Extract and Vitamin C Feed Supplementation on Some Blood Parameters and HSP70 Gene Expression of Broiler Chickens Suffering from Chronic Heat Stress. Ital. J. Anim. Sci., 14:1-9.

Hughes, RJ; Brooker JD and Smyl C., 2005. Growth rate of broiler chickens given condensed tannins extracted from grape seed. Australian Poultry Science Symposium, 17, 65-68.

Ismail, AM; Sedki AA and Abdallah AG., 2003. Influence of black seed, garlic and onion supplementation on reproductive performance and immune functions in rabbits. Egyptian Journal Agriculture Research, 81, 1193-1207.

Jakobsen , PE; Kirston SG and Nielsen H., 1960 .Digestibility trails with poultry . 322 bretning fra foprsgs labratriet udgivest statens .Husdybug sudvalg kobenhann.
Katiyar, SK., 2015. Proanthocyanidins from grape seeds inhibit UV-radiationinduced immune suppression in mice: detection and analysis of molecular and cellular targets. Photochemistry and Photobiology 91, 156-162.

Kermauner, A. and Laurenčič A., 2008. Supplementation of rabbit diet with chestnut wood extract. Effect on invitro gas production from two sources of protein. In: Proceedings of the $9^{\text {th }}$ World Rabbit Congress, Verona, June10-13, 2008, pp.689-693

Lee, MH; Lee HJ and Ryu PD., 2001. Public health risks: chemical and antibiotic residues. Review. Asian-Aust. Jo. Anim. Sci., 14: 402- 413.

Llobera, A and Canellas J., 2007. Dietary fiber content and antioxidant activity of Manto Negro red grape (Vitis vinifera): Pomace and stem. Food Chem. 101,659-666

Nardoia, M., 2016. Effect of dietary polyphenol-rich grape byproducts on growth performance, some physiological parameters, meat and meat products quality in chickens, $\mathrm{PhD}$ thesis. Institute of Food Science Technology and Nutrition, the Spanish Science Research Council (CSIC), Madrid, Spain.

Pascariu SMI; Pop IMI; Simeanu DI; Pavel GI and Solcan CI (2017). Effects of wine by-products on growth performance, complete blood count and total antioxidant status in broilers. Brazilian Journal of Poultry Science, vol.,19: 191-202

SAS Institute. (2004). SAS User's Guide: Statistics. Edition 9.1 . SAS Institute Inc., Cary, NC.

Singh, MK; Singh SK; Sharma RK; Singh B and Kumar S., 2015. Performance and carcass characteristics of guinea fowl fed on dietary Neem (Azadirachta indica) leaf powder as a growth promoter. Iran. J. Vet. Res.,16:7882.

Toscano, G; Riva G; Duca D; Pedretti EF; Corinaldesi F and Rossini G., 2013.Analysis of the characteristics of the residues of the wine production chain finalized to their industrial and energy recovery. Biomass and Bioenergy, $55,260-267$

Viveros, A; Chamorro S; Pizarro M; Arija I; Centen C and Brenes A., 2011. Effects of dietary polyphenol rich grape products on intestinal microflora and gut morphology in broiler chicks. Poult. Sci, 90: 566-578

Wang, ML; Suo X; Gu JH; Zhang WW; Fang Q and Wang X., 2008. Influence of grape seed proanthocyanidin extract in broiler chickens: effect on chicken coccidiosis and antioxidant status. Poultry Science 87, 2273-2280.

Xia, EQ; Deng GF; Ya-Jun Guo YJ and Hua-Bin LHB., 2010. Biological activities of polyphenols from grapes. International Journal of Molecular Sciences ,11, 622646.

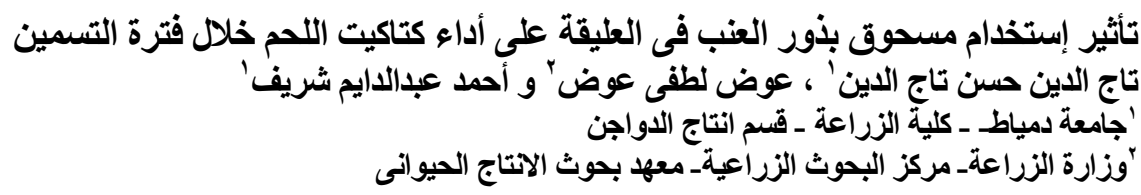

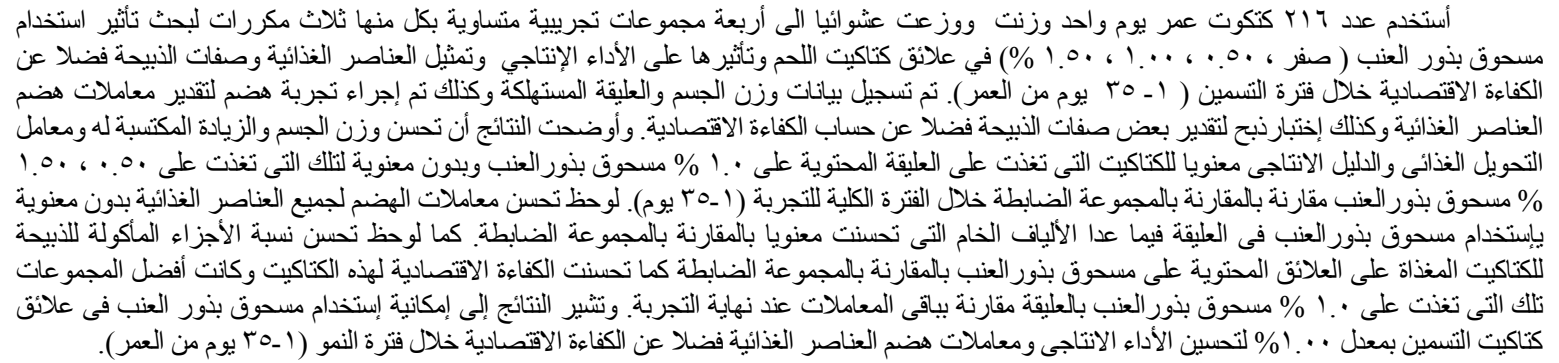

